\title{
Anna Akhmatova: The evolution of poetic identity
}

\author{
Isaeva G.A. ${ }^{1}$, Rozikova N.N. ${ }^{2}$ \\ ${ }^{1,2}$ Bukhara State University, Uzbekistan \\ Email:gulung@mail.ru
}

\begin{abstract}
The article deals with the evolution of poetic identity of Anna Akhmatova on the examples of the early collections "Evening" (Vecher, 1912), "Beads" (Chetki, 1914), "White Flock" (Belaia Staia, 1917) in the aspect of subject, genre and style and with the perception of the poetess' works by intravital and contemporary critics.
\end{abstract}

Keywords: Akhmatova, genre, style, poetic identity, evolution, subject, critics.

\section{INTRODUCTION}

"The name of Akhmatova immediately became famous and beloved for the whole of young Russia,". "If the muse of the Symbolists saw in the image of a woman a reflection of the eternal, Akhmatova's poems speak of unchangeable. The mystical deepening, epiphany and enlightenment disappeared. This spiritual peculiarity makes us rank Akhmatova among those who have overcome symbolism; her poetic talent makes her the most significant poet of the young generation, "wrote V. Zhirmunsky in the article" Overcome Symbolism" (1916) [1, p. 32, 41]. According to the modern researcher I. Gurvich, on the one hand, the poet's legacy is perceived as a whole, having end-to-end aesthetic dimensions; on the other, important differences are evident between the two main components of the heritage. They are in the subject, in their internal connections as well as in the organization of a separate poem [2]. The first poetry collection "Evening" (Vecher, 1912, 300 copies) drew the attention of readers and critics to the young poet. An increase of the print run of the second book, "Beads" (Chetki, 1914, 1100 copies), testified to the growth of Akhmatova's fame. The third pre-revolutionary poetry collection, The "White Flock" (Belaia staia, 1917), was also very popular. All the pre-revolutionary books of Akhmatova were constantly reprinted, verses were memorized, people who knew her closely admired her creativity, personality, and appearance. Then two more books followed, completing the first period of creativity - "Plantain" (Podorozhnik, 1921) and "Anno Domini MCMXXI" (1922). Her first five collections, from "Evenings" (Vecher, 1912) to "Anno Domini MCMXXI" (1922), are written on one topic, the theme of love, and make up an almost uniform array - deviations from uniformity are few and significant: responses to a historical event - the First World War ("Prayer" (Molitva), "In Memory of July 19, 1914", "July 1914"), a declaration of the author's position at the time of social cataclysms ("I had a voice...", "I am not with those who threw the earth..."), protection of moral dignity ("Solitude" (Uyedeneniye), "Slander" (Kleveta)). Poems not about love show the poet's involvement in the superpersonal sphere of being and life. However, the supremacy of the intimate personal principle remains unshaken: revelations addressed to the depths of the soul outline the individuality of the lyrical "I" and thereby justify its right to civic pathos. Poems about love form, in fact, the background of programmatic poetic statements [2]. The general theme of love comprises more than two hundred poems, and Akhmatova wrote about unhappy love from her personal experience. Akhmatova became the "Russian Sappho", thanks to her talent the woman for the first time in the history of Russian poetry found her voice.

According to the remark of K.I. Chukovsky, she comprehensively developed this topic and in Russian poetry she was, "the first to find that being unloved is poetic" [3, p. 184]. The poem of 1911, "Gripped her hands under a dark veil ..." is autobiographical, it recreates the psychologically tense relationship of Anna Gorenko and Gumilyov before their marriage. The lyrical heroine conducts a dialogue with her conscience, through her actions and speech the inner confusion of the girl who realized her guilt before the departing hero was conveyed. At the same time, the poem is perceived not only as a lyrical work itself, but as a scene from a novel or short story. The drama of the situation of a loving girl is 
pronounced in "excerpt" (Otryvok, 1912), which reveals different types of love - the meek, humble love, the victim of the lyrical heroine - and the cruel of her imperious lover.

Thus, the poet, following F. Dostoevsky, recreates his ideas about the antinomies of the Russian character. It is no accident that O. Mandelstam wrote about Akhmatova: "Akhmatova brought to the Russian lyrics all the enormous complexity and psychological richness of the 19th century Russian novel". "The genesis of Akhmatova lies in Russian prose, and not in poetry. She developed her poetic form, sharp and peculiar, with an eye on psychological prose "[4, p. 57-58].

However, a significant place already in Akhmatova's early work was also taken by the image of Pushkin and the Pushkin theme, which was manifested in the third poem from the cycle "In Tsarskoye Selo" (1911): The dark-skinned lad wandered along the alleys, Near the lake sad banks, And for a century we cherish the barely audible rustle steps. Pine needles densely and stabbing Low stumps are strewn ... Here lay his cocked hat And disheveled volume Guys [5, p. 77]. This poem, capacious in figurative means and artistic techniques, is the third in this cycle, especially noteworthy, since in it the poet emphasizes her adherence to the Russian poetic tradition. With the help of precise subject details, landscape descriptions, an image of a young Pushkin was created. The elegance of Pushkin's early lyrics is emphasized by the verb of the state "sad", the inherent melody is transmitted by purely verbal means thanks to alliterations to "l", "m", "n", "r". Alliteration to "/sh/" in the line "Barely rustling steps" creates the artistic effect of a sound metaphor. At the same time, in the early Akhmatian lyrics, classical genres are not often found, she will turn to the elegia genre at the end of her first creative period (the "Northern Elegies" cycle began in 1921). Akhmatova made an exception for the message "To Alexander Blok" (1914), short stories and ballads. In an addiction to the third genre form, most likely, N.S. Gumilyov, an expert and admirer of French poetic classics had an impact on poetess. The atmosphere of Gumilev's romance is palpable in the early masterpiece of 1910, the ballad "The Grey-eyed King": the soil on which the action takes place is foreign, generalized Central European, stylized according to the Middle Ages, as evidenced by the following realities - royal hunting, old oak. Linguistic means correspond to such a chronotope, an adjective of a short form - " The autumn evening was quiet and red." The last linguistic peculiarity brings together the poetics of young Akhmatova with the style of lyrics from the Yesenin collection "Radunitsa" (Ritual for the Dead). The characters of the ballad are the king, his wife and lover, their daughter, husband of the lover. The pair rhyme is reminiscent of the mood of a medieval French lyric ballad. Captive psychologism and psychological parallelism, which have become significant signs of the Akhmatov style, are the leading ways of revealing the inner world of a person in a poem. The feelings of the lyrical heroine are contradictory, they combine pain and pride in this pain ("Glory to you, hopeless pain! / The gray-eyed king died yesterday"), since the deceased beloved heroine of the ballad is a monarch, the grief of the widowed queen skillfully conveyed in one line ("During the night she became gray one "). Like the heroes of Russian folk songs, the lyrical heroine of Akhmatova is connected with the natural world, in the noise of poplars she hears the sad news: "But the poplars are rustling over the window:

"You have no your grey-eyed king now". But still, Despite the manifestation of the grief of the lyrical heroine, the poem triumphs the wise acceptance of the laws of human existence as a link between generations: it is no accident that the same detail is mentioned at the end of the work as at the beginning the grey eyes of the king and the daughter of the king, and the lyrical heroine. Such a ring composition completes the story of the woeful event and the musicality inherent in the ballad genre

The "Grey-eyed King" testified to the variety of Akhmatova's artistic means and techniques in developing the theme of unhappy love: a fascinating, melodramatic plot is based on a love "polygon". The strict attitude to herself as a poet, inherent in young Akhmatova, was manifested in the writing of two versions of the text "Grey-eyed King", which testified to the great talent of the poetess.

Akhmatova's poetry caught the attention of thoughtful readers, including critics, acmeist poets S. Gorodetsky and M. Kuzmin. The first one praised the "Evening": "The graceful sorrow, the ungodliness and the ingenuousness of this book immediately became dear to many" [6, p. 124]. In the preface to the "Evening", which was lyrical as a diary, Kuzmin called Akhmatova a "material lover" and emphasized her femininity: “... unlike other material lovers, Anna Akhmatova has the ability to understand and love things precisely in their incomprehensible connection with the experienced moments," "we especially appreciate the first understanding of the acute and incomprehensible meaning of things, which is not so 
common". Akhmatova even compared natural phenomena with things: "A cloud high up in the sky was gray, / Like a squirrel spread skin". We add that the verses from the first book of Akhmatova are marked by general modernist myth-making - the presence of the lyrical heroine and the heroes of her verses in doubles. The origins of Akhmatov's myth-making go into Slavic mythology and Old Russian culture, into the tales of the peoples of Europe: Snow Maiden, mermaid ("A cloud was gray high in the sky...", "I don't need more of my feet ..."), Russian mythological bird Sirin, prince from lyric poems and the early poem "By the Blue Sea", Sandrilon, Cinderella, and the Prince. At the same time, Akhmatova, like her companion Mandelstam, takes inspiration from ancient mythology, especially Muse (1913 cycle "Epic motifs" and other poems). This image is also important in the 1936 poem "Voronezh" dedicated to Osip Mandelstam and written by Akhmatova on March 4, 1936 after visiting Mandelstam in the Voronezh exile: "...And in the room of the disgraced poet, fear and Muse are on duty. And the night is coming, which does not know the dawn..." [5, p. 429]. The collection "Rosary" became an indicator of the creative evolution of Akhmatova. The meaning of the title of the book is religious, it consists in bringing together beads of beads with the memories of the lyrical heroine [8]: sorting through the beads, she recalls the past. Now she has become more ascetic, self-critical, and demanding of herself and people of her circle ("We are all roisterers here, harlots..."). Chukovsky described the author of the "Rosary" as follows: "the most Christian lyric poet of our era" [3, p. 182]. The book is dominated by moral and philosophical themes of farewell to the past, memory, love, faith, death. The motive for parting with your beloved sounds in the epigraph to the book taken from the poem by E.A. Baratynsky, and in the poems "I do not ask for your love...", "I took my friend to the front...", "So many requests from my beloved always!", The first of which is closest in tone and increased expressiveness to Marina Tsvetaeva. The memory of the poem "In the straps of the pencil case and the books were..." about the first meeting with N. Gumilyov she calls him "grey swan", "Dying, languishing for immortality ..." (1912), about the childhood and youth of the "seaside girl" from the poem "I see a faded flag above the customs...", 1913 [see: 9]. The theme of memory prevailing in this book is intertwined with the love theme that dominates here. Developing love issues in her own way, Akhmatova uses a rich arsenal of imagery of Russian poetry of the Golden Age, which can be seen in the poem of 1914, "After the wind and frost it was ...:

"After the wind and frost it was pleasing to keep myself warm by the fire. There I did not follow my heart, so it was stolen from me.

New Year's holiday lasts magnificently, The stems of New Year's roses are moist, And in my chest I can't hear the Flutter of dragonflies".

Oh! It's not difficult to guess the thief, I recognized him by the eyes. Only it's scary that very soon he will return his prey himself' [5, p. 170].

In the subtext of the work, the metaphor "love - flame, fire", often found in the poetry of Alexander Pushkin and the poets of the Pushkin circle, Yevgeny Baratynsky. But already Mikhail Lermontov had a desire to renew this metaphor, whose internal form began to become impoverished ("Love, like a plague spot on the heart: It burns, although it is dark"). Akhmatova's innovation is even more noticeable, like Mayakovsky ("Cloud in Pants"), who romanized and embodied this metaphor, turned a metaphorical flame into a real fire in a fireplace or in someone's family hearth and layered another metaphor "love flame, fire" into another metaphor "steal someone's heart". The heart of the lyrical heroine was stolen by a certain "thief", that is, the hero who was carried away by her, therefore the fire of love flashes in her heart. So one of the classic images of European lyrics is updated. Inside the theme of love in the "Rosary" stands out the motive of a date. The date is still dramatic ("Evening"). Among the poems of the collection, the three-part cycle "Confusion", also written on the theme of love, is significant. Marked by Zhirmunsky, Akhmatova's artistic methods in "The Rosary" are basically the same as in the "Evening": in the poem "Took my friend to the front..." enjambments convey confusion of feelings, landscape and subject details enter the character's image into the natural world: "Thrown! A coined word - / Am I a flower or a letter?". Merging with the nature of the lyrical heroine helps her overcome the sadness of breaking with her beloved and find spiritual harmony. The portrait detail of the grey eyes of the hero from different poems of the collection is also stable. Towards the end of the Rosary, the lyrical heroine, after all the love losses suffered by her and the wounds inflicted by her beloved (the tortured "owlet"), loses freedom in the field of manifestation of feelings and in return acquires Christian faith, meekness, admiration for the beauty of God's world: "I learned simply, wisely live, Look at the sky and pray to God, 
And wander long before the evening, In order to tire unnecessary anxiety.” [5, p. 98]. At the same time, Akhmatova does not have a mystical self-deepening characteristic of the Symbolists. The appearance of the lyrical heroine also changes: instead of a narrow skirt of a regular cafe visitor, a modest everyday dress, worn-out heels of a loving and devoted woman; rosary, "worn rug under the icon." Among the best works of this collection, the poem of 1913 stands out: "You know, I languish in captivity ...":

"You know, I languish in captivity, praying for the death from the Lord. But I remember painfully Tver's meager land.

Crane at a dilapidated shaft, Above it, like a boil clouds, In the fields creaky collars, And the smell of bread, and longing.

And those dim expanses, Where even the voice of the wind is weak, And condemning the eyes of Calm tanned women [5, p. 143].

The motive for imminent death sounds in this poem, which was noted by Gumilev in the review of the collection "Rosary": "Like most young poets, Anna Akhmatova often has words: pain, longing, death. This natural and therefore beautiful youthful pessimism was still the property of pen samples "[10, $p$. 174]. What was new in this work was the fact that here was a concrete image of Russian land, (in contrary to "Grey-eyed King") images of commoners are drawn. This poem by Akhmatova, who condemned, according to the memoirs of her contemporaries, Sergei Yesenin for the poetry of his small homeland, Ryazan, [8](in early Yesenin poetry) due to its patriotism, nationality and stylistic simplicity. So a new direction was outlined in the creative development of the poetess.

From critical responses the "Rosary" received review from Nikolai Gumilev and the article by N. Nedobrovo, published shortly after the release of the first two Akhmatov collections: "...compared to The Evening, published two years ago, Rosary is a big step forward. The verse became harder, the content of each line became denser, the choice of words became chastely mean... She almost never explains, she shows."[10, p. 177, 176] - wrote Gumilev. Unkindly emphasized: the central motive of the "Rosary" is "unhappy love", but not limited by its own meaning, but stimulating "penetration into a person", into an outstanding female character. "And yet - it is necessary to endure a lot of suffering in order to turn to the person who came to console, with these words: What now I have mortal languor! If you still stay with me, I will beg forgiveness from God for both you and everyone you love. Such self-forgetfulness is given not only at the cost of great suffering, but also great love "[11]. According to Nedobrovo, "not only the suffering of unhappy love expresses the lyrics of Akhmatova. In a smaller number of poems, but by no means with less force, she sings of another suffering: acute dissatisfaction with oneself"[Ibid.].

\section{CONCLUSION}

Totally, in 1916, on the eve of the release of the third book, "The White Flock", O. Mandelstam wrote in an unpublished review of the collection of verses Anthology of Muses: "In the last verses of Akhmatova there was a turning point to the supreme importance, religious simplicity and solemnity: I would say after women it was the wife's turn... The voice of renunciation is growing stronger and more in the verses of Akhmatova, and now her poetry is approaching to become one of the symbols of Russia's greatness "[12, p. 44]. These words were not accidentally written after the First World War began, and on the eve of the revolution. Akhmatova's third book includes 83 poems and the poem "Near the Sea". Intimate experiences faded into the background, and civilian lyrics came to the fore. Accordingly, the poetic means also changed - conversational intonations gave way to prayer ones, as in the 1915 poem "Prayer". The loneliness of the lyrical heroines of "Evenings" and "Rosary" in the third book is replaced by "choral polyphony", and Akhmatova's poetry becomes an expression of popular consciousness. This vector will be further developed in the post-revolutionary work of the poetess.

\section{REFERENCES}

1. Zhirmunsky V.M. Overcome Symbolism // Russian Thought. - 1916.- Issue. 12. - p. 32, 41. (Page 2).

2. Chukovsky K.I. Akhmatova and Mayakovsky // "Voprosy Literaturi” journal. - 1988. - Issue. 1. - p. 184. 
3. Mandelstam O.E. A letter about Russian poetry // O.E Mandelstam Omnibus edition and letters: in 3 vols. - M.: Progress-Pleiades, 2010. vol. 2. Prose. - p. 57-58.

4. Akhmatova A.A. Omnibus Edition: 6 vols. - M .: Ellis Luck, 1998. vol.1. Poems. 1904-1941 / comp., Preparation. text, comment. and article N.V. The queen. - p. 77.

5. Gorodetsky S.M. Some trends in modern Russian poetry // Literary manifestos: From symbolism to October. - M., 2001. - p. 124.

6. Kuzmin M. Preface // Akhmatova A.A. Evening. - SPb., 1912. - p. 8-9.

7. Kralin M. Unknown about Anna Akhmatova // "Nash Sovremennik" journal. - 2000. - Issue. 3. p. 236-245.

8. Kormilov S.I. A.A. Akhmatova // History of Russian literature of the XX-century (20-90s). Main names. - M., 1998 .-- S. 317-344.

9. Gumilev N.S. Omnibus edition 10 vols. - M .: Sunday, 2006.

10. Nedobrovo N. Anna Akhmatova // http://www.silverage.ru/poets/nedobrovo_ahmatova.html (accessed date: 01/12/2019).

11. Mandelstam O.E. About modern poetry (To the output of the "Anthology of muses") // Mandelstam O.E. Omnibus edition and letters: in 3 vols. - M.: ProgressPleyada, 2010. vol. 2. Prose. - p. 44.

12. Gurvich I. Love lyrics by Akhmatova (integrity and evolution) // "Voprosy Literatury" journal. 1997. - Issue. 5 // http://magazines.russ.ru/voplit/1997/5/gurvich.html (accessed: 03.12.2019). 